\title{
РОЗВИТОК ТУРИЗМУ ЯК ОДИН ІЗ ПЕРСПЕКТИВНИХ НАПРЯМІВ ПОДОЛАННЯ МАКРОЕКОНОМІЧНИХ ПРОБЛЕМ КРАЇНИ В УМОВАХ ТРАНСФОРМАЦІЇ СУСПІЛЬСТВА
}

\section{Рецензент - доктор економічних наук, професор Л. М. Березіна}

Обгрунтована важливість туристичної галузі як одного з перспективних напрямів вирішення широкого кола макроекономічних проблем у період трансформації суспільства, щзо дозволить стабілізувати соціально-економічну ситуацію у краӥні й поліпшити якісні характеристики життя населення. Визначені провідні напрями впливу туристичної діяльності на розвиток краӥни та причини, щуо їх обумовлюють. Наголошується, щзо досягнення поставлених изілей буде можливим лише за умови послідовних $і$ відповідальних дій влади, ї̈ постійної взаємодї з громадськістю, бізнесом.

Ключові слова: економіка, туризм, туристична індустрія, туристична галузь, соиіально-економічні проблеми, трансформачія суспільства.

Постановка проблеми. Важливою складовою світової економіки виступає туристична галузь. У 2012 році World Travel \& Tourism Council опублікувала звіт «Бенчмаркінг - подорожі та туризм», де зазначено, що в умовах глобального ВВП у галузі туризму працюють у 6 разів більше людей, аніж в автомобільній промисловості, в 5 разів більше, ніж у світовій хімічній промисловості, в 4 рази більше, ніж у світовій гірничодобувній промисловості, вдвічі більше, ніж у світовій комунікаційній індустрії, й на третину більше, ніж у глобальній індустрії фінансових послуг [10]. Прямий економічний ефект від впливу на світові економічні процеси індустрії туризму підтверджують майже $6 \%$ світового валового національного продукту, $7 \%$ світових інвестицій, $5 \%$ усіх податкових надходжень, кожним 16-м робочим місцем, $11 \%$ світових споживчих витрат, збільшенням обсягів валютних надходжень за період з 1950 по 2003 рік у 144 рази [8].

В Україні також усвідомили важливість туристичної галузі як одного з перспективних напрямів вирішення таких соціально-економічних проблем країни, як падіння життєвого рівня населення; збільшення безробіття; зростання загрозливого за масштабами соціального розшарування суспільства; посилення міграційних потоків із країни тощо. Усвідомлюючи це, 14 серпня 2013 р. Кабінет Міністрів затвердив список пріо- ритетних галузей економіки, серед яких і курортнорекреаційна сфера й туризм.

Аналіз основних досліджень і публікацій, у яких започатковано розв'язання проблеми. Проблеми розвитку туристичної проблематики знаходяться в центрі уваги багатьох українських дослідників, які аналізуть різні аспекти іiі розвитку. Це зокрема: М. Н. Максимюк [6], І. М. Писаревский, Н. Б. Петрова [8], С. П. Грабовенська [3], Е. А. Поліщук, А. Ю. Колдіна [7] та інші. Значну наукову цінність мають вітчизняні $[9,14]$ й міжнародні аналітичні матеріали $[12,12]$. Прикладом комплексного бачення розвитку туристичної галузі є державні програми [5, 13], зокрема Державна цільова програма розвитку туризму до 2022 року (доручено розробити Державному агентству 3 туризму та курортів), основними завданнями якої $\epsilon$ : створення системи держпідтримки галузі, вдосконалення законодавства в сфері туризму, забезпечення раціонального використання та охорони туристичних рекреаційних ресурсів, поширення інформації про туристичні можливості України на міжнародному ринку та всередині держави, модернізація рекреаційно-курортної сфери.

Мета дослідження полягає в тому, щоб 3'ясувати роль та значення туристичної галузі відповідно до сучасних макроекономічних потреб країни в контексті забезпечення гідного рівня життя ії громадян.

Завдання: визначити провідні напрями впливу туристичної діяльності на соціально-економічний розвиток країни та причини, що їх обумовлюють.

Методи дослідження: аналітичний, порівняльний, статистичний методи.

Результати досліджень. Туристична галузь має високий мультиплікативний ефект, який впливає на 48 галузей економіки країни [5], тому Всесвітня рада подорожей і туризму (WTTC) розглядає ії внесок у ВВП - провідний макроекономічний індикатор розвитку країни - як складну систему, до якої входять $[11$, с. 2]:

1. Прямі витрати туристів на здійснення подо- 


\section{EKOHOMIKA}

рожей (такі як поїздки, розміщення, розваги, відвідування визначних пам'яток і музеїв, харчування і т. д). Розглядаються витрати внутрішніх, в"їзних туристів і витрати на поїздки на державному рівні у відповідності 3 рекомендованою OОН методологією туристичних рахунків (TSA: RMF 2008).

2. Непрямі внески туристичної сфери в економіку країни включають інвестиції в туристичну галузь (будівництво туристичної інфраструктури, придбання транспорту та обладнання), державні витрати на туристичну сферу (маркетинг, забезпечення безпеки, адміністрування тощо), внутрішні закупівлі продуктів і послуг підприємствами туристичної сфери (закупівля продуктів харчування, послуги 3 прибирання, забезпечення ІТ-послуг і т. д.).

3. Індукований внесок у ВВП країни визначається як витрати тих, хто прямо чи опосередковано отримує дохід у туристичній сфері.

Так, згідно з рейтингом Всесвітньої ради з туризму і подорожей, загальний внесок туристичної сфери у ВВП України у 2012 р. становив 92,1 млрд гривень.

При цьому прямі витрати туристів становили 24,6 млрд грн, або 26,7 \%, непрямий внесок туристичної галузі в економіку склав 56,4\%, або 51,9 млрд грн, індукований внесок становив 16,9\%, або на 15,6 млрд грн [11, с. 6].

Передбачається, що в найближчі десять років внесок туристичної галузі у ВВП країни сягатиме $5 \%$ (нині вона формує $2,2 \%$, у Свропі - $8 \%$, в окремих країнах - близько $20 \%$ ) [10].

Туризм - це галузь, що стимулює інвестиційну діяльність зі створення нових робочих місць.
Дослідження показують, що на 1 тис. туристів, які зупиняються в готелях, створено 279 місць працевлаштування в самому туризмі та 107 - для зайнятості, не пов'язаної з туризмом безпосередньо, а саме - на будівництві та ремонті об'єктів розміщення туристів, у харчовій промисловості, сільському господарстві, у сферах обслуговування (на транспорті, в закладах, що беруть участь у організації видовищних заходів, спортивних змагань, об'єктах ресторанного і готельного бізнесу тощо).

За даними офіційної статистики, у 2012 році в сфері туризму (у готелях, на транспорті, в ресторанах і кафе, в культурних центрах) було зайнято 380 тисяч працівників, а з урахуванням зайнятих у суміжних галузях - 1,4 млн осіб [2].

У відповідності з планами Державної цільової програми розвитку туризму до 2022 року, передбачено лише в туристичній галузі створити близько мільйона робочих місць [2], що важливо в умовах майже 8,6 \% безробіття в країні, хоча по регіонах цей показник може різнитися (табл. 1).

Перспективним напрямом залучення до цього виду діяльності (з досвіду інших країн) визнано розвиток малого бізнесу, який не вимагає значних капітальних вкладень, але сприяє покращанню (розвитку) необхідної інфраструктури, тому за світовою статистикою найбільш адаптовані до роботи у сфері туризму саме жінки (і молодь) [8]. Це дозволить їм поліпшити своє матеріальне становище, адже зарплата жінок в Україні становить у середньому лише $73 \%$ зарплати чоловіків (за одну відпрацьовану годину чоловік отримує 2,53 грн, а жінка - 1,92 грн) (табл. 2).

\section{1. Рівень безробіття по регіонах Украӥни, 2013 р.}

\begin{tabular}{|c|c|c|c|c|c|c|c|c|}
\hline $\begin{array}{c}\text { Регіон } \\
\text { (область) }\end{array}$ & $\begin{array}{c}\% \\
* a\end{array}$ & $\begin{array}{c}\% \\
\sigma^{*}\end{array}$ & $\begin{array}{c}\text { Регіон } \\
\text { (область) }\end{array}$ & $\begin{array}{c}\% \\
* a\end{array}$ & $\begin{array}{c}\% \\
\sigma^{*}\end{array}$ & $\begin{array}{c}\text { Регіон } \\
\text { (область) }\end{array}$ & $\begin{array}{c}\% \\
* a\end{array}$ & $\begin{array}{c}\% \\
\sigma^{*}\end{array}$ \\
\hline Україна & 7,6 & 8,6 & Ів.-Франківська & 7,4 & 10,3 & Сумська & 8,4 & 10,7 \\
\hline Крим & 5,8 & 7,2 & Київська & 6,3 & 9,9 & Тернопільська & 10,2 & 13 \\
\hline Вінницька & 9,2 & 11,6 & Кіровоградська & 8,5 & 10,3 & Харківська & 6,7 & 7,1 \\
\hline Волинська & 8,3 & 12,6 & Луганська & 6,5 & 6,7 & Херсонська & 6,7 & 12,1 \\
\hline $\begin{array}{c}\text { Дніпро- } \\
\text { петровська }\end{array}$ & 6,6 & 10,3 & Львівська & 7,4 & 8,5 & Хмельницька & 8,7 & 12,2 \\
\hline Донецька & 8,2 & 7,8 & Миколаївська & 7,8 & 7,9 & Черкаська & 9,0 & 11,4 \\
\hline Житомирська & 10,1 & 9,8 & Одеська & 5,7 & 8,6 & Черновицька & 8,6 & 9,6 \\
\hline Закарпатська & 7,6 & 9,2 & Полтавська & 8,5 & 9,6 & Чернігівська & 10,3 & 10,4 \\
\hline Запорізька & 6,8 & 8,1 & Рівненська & 10,2 & 7,0 & Київ & 5,6 & 8,3 \\
\hline
\end{tabular}

Складено автором. Джерело: [1].

a* - дані Держкомстату, б* - дані Міжнародного центру перспективних досліджень 
ЕКОНОМІКА

\section{2. Гендерне співвідношення рівнів доходів [1]}

\begin{tabular}{|c|c|c|c|c|c|}
\hline Регіон & $\%$ & Регіон & $\%$ & Регіон & $\%$ \\
\hline Вінницька & 81,9 & Кіровоградська & 81,0 & Харківська & 77,0 \\
\hline Волинська & 83,4 & Луганська & 66,15 & Херсонська & 84,1 \\
\hline Дніпропетровська & 65,5 & Львівська & 74,5 & Хмельницька & 80,2 \\
\hline Донецька & 60,2 & Миколаївська & 73,5 & Черкаська & 80,0 \\
\hline Житомирська & 82,8 & Одеська & 76,7 & Черновицька & 84,5 \\
\hline Закарпатська & 80,4 & Полтавська & 72,9 & Чернігівська & 82,0 \\
\hline Запорізька & 67,8 & Рівненська & 73,7 & Київ & 79,1 \\
\hline Ів.-Франківська & 72,5 & Сумська & 76,5 & Севастополь & 71,2 \\
\hline Київська & 73,1 & Тернопільська & 83,6 & Крим & 80,4 \\
\hline
\end{tabular}

Згідно з всеукраїнським опитуванням дослідницької компанії Research \& Branding Group, проведеного в квітні 2012 року, близько $20 \%$ українців на туризм і відпочинок витрачають не більше 620 доларів у рік, понад половину населення України $(59,7 \%)$ не вкладають в загальну туристичну скарбничку ні копійки. Підтверджують цю тенденцію результати опитувань, представлені у 2012 р. журналом «Кореспондент», Київським міжнародним інститутом соціології, спільними дослідженнями фонду «Демократичні ініціативи» та Центру Разумкова (табл. 3).

\section{3. Украӥнці й туризм"}

\begin{tabular}{|c|c|c|c|}
\hline Українці & $\%$ & Українці & $\%$ \\
\hline $\begin{array}{c}\text { Ніколи не були } \\
\text { за кордоном }\end{array}$ & 77 & $\begin{array}{c}\text { Виїздили } \\
\text { за кордон }\end{array}$ & 3 \\
\hline $\begin{array}{c}\text { Не виїздили } \\
\text { навіть за межі } \\
\text { рідного регіону } \\
\text { (області) }\end{array}$ & 36 & $\begin{array}{c}\text { Відвідували } \\
\text { країни ЄС, } \\
\text { США чи Канаду }\end{array}$ & 17 \\
\hline
\end{tabular}

* Складено автором. Джерело: [4]

Одна з причин такого становища - відсутність у переважної частини населення фінансових можливостей, його бідність (крайня нестача майнових цінностей, товарів, грошових коштів для

\section{БІБЛІОГРАФІЯ}

1. Гнатив О. Где в Украине жить хорошо // Weekly UA. - 201, №34. - C. 14-25.

2. Государство решило вкладывать средства в туризм. [Электронный ресурс]. - Режим доступа: http // kpravda.com/gosudarstvo-reshilo-vkladyvatsredstva-v-turizm/

3. Грабовенська С. П. Современное состояние и тенденции развития туристической сферы в Украине [Электронный ресурс]. - Режим доступа http://www.marketolog.info/index.php/market/12turizm/214-2013-07-31-07-30-09 нормального життя і життєдіяльності людини). За даними соціологічних досліджень, 55 відсотків українців у середньому витрачають понад половину свого заробітку на продукти харчування, окрім того (за самосприйняттям) бідними вважають себе $85 \%$ жителів України, в тому числі за межею бідності проживає 18,7 \% жінок. Отже, розвиток туризму допоможе вирішувати не лише проблему бідності, але й подолання гендерної нерівності в доходах.

Висновок. Туристичну галузь можна розглядати як один із елементів механізму, спрямованого на подолання кризової ситуації, перспективний напрям соціально-економічного розвитку країни. Досягнення поставлених цілей буде можливим лише за умови послідовних і відповідальних дій влади, іiї постійної взаємодії з громадськістю, бізнесом. Для підвищення результативності українського туристичного бізнесу як умови подолання макроекономічних проблем у трансформаційний період не завадить досвід провідних країн світу. Водночас слід враховувати двоякий характер розвитку туристичної сфери: в період соціально-економічної, політичної стабільності вона демонструє позитивну динаміку, а в період кризи вона одна 3 перших зазнає відчутних втрат.

4. Кабачий Р. Выглядывая из-за Кураю // Комментарии. - 2013. - №18. - 10 мая. - С. 13.

5. Кабинет министров Украины. Постановление от 29 апреля 2002 № 583 «Об утверждении Государственной программы развития туризма на 20022010 годы». - [Электронный ресурс]. - Режим доступа: http://zakon4.rada.gov.ua/laws/show/583-2002$\% \mathrm{D} 0 \% \mathrm{BF}$

6. Максимюк М. Н. Оценка состояния и перспективы развития индустрии туризма в Украине // Культура народов Причерноморья. - 2012. - Куль- 


\section{ЕКОНОМІКА}

тура народов Причерноморья. - 2012. - №235. C. 55-61. [Электронный ресурс]. - Режим доступа: http://tourlib.net/statti_tourism/maksimjuk7.htm

7. Полищук Е. А., Колдина А. Ю. К вопросу о кадровых проблемах в сфере туризма Украины: http://conference.be5.biz/r2012/3267.htm

8. Писаревский И. М., Петрова Н. Б. Предпосылки анализа уровня развития туристской сферы регионов Украины. - См: http://www.confcontact.com /2008dec/4_pisarev.php

9. Рынок туризма в Украине. [Электронный ресурс]. - Режим доступа: http//www.proreklamu.com /news/researches/25936-rynok-turizma-v-ukraineobzor.html
10. Украина активно рвется в мировые туристические лидеры. - [Электронный ресурс]. - Режим доступа: http//inpress.ua/ru/politics/14892ukraina-aktivno-rvetsya-v-mirovye-turisticheskielidery.

11. Travel \& Tourism Economic Impact 2012 Ukraine / World Travel \& Tourism Council / London 2012/24 c12. World Travel \& Tourism Council. [Электронный ресурс]. - Режим доступа: http://www.answers.com/topic/world-travel-andtourism-council

13. http://www.rbc.ua/rus/news/economic/realizat siya-programmy-razvitiya-turizma-i-kurortov-do2022-03062013173400 